URL: http://ojs.unimal.ac.id/index.php/ekonomi pertanian

\title{
Faktor-Faktor Yang Mempengaruhi Pendapatan Petani Kelapa Sawit (Studi Kasus Di Kabupaten Pasaman Barat Kecamatan Ranah Batahan)
}

\author{
Naf'an Pangidoan ${ }^{\mathrm{a}^{*}}$,Devi Andriyani ${ }^{\mathrm{b}^{*}}$ \\ ${ }^{a}$ Fakultas Ekonomi dan Bisnis Universitas Malikussaleh \\ $\mathrm{a}^{*}$ Corresponding author : nafannafan4@gmail.com \\ $b^{*}$
}

ARTICLE INFORMATIONABSTRACT

Keywords:

Experience, Age, Working Time, Production, Income

ABSTRACT

This study aims to analyze the factors that influence the income of oil palm farmers in Ranah Batahan District, West Pasaman Regency. The data used in this research is secondary data. The method used to analyze the relationship between variables is multiple linear regression analysis. The results showed that work experience, age, working time and production had a positive and significant effect on the income of oil palm farmers in Ranah Batahan District, West Pasaman Regency. Simultaneously, business experience, age, working time and production affect the income of oil palm farmers in Ranah Batahan District, West Pasaman Regency.

\section{PENDAHULUAN}

Indonesia telah dikenal sebagai negara agraris. Hal ini disebabkan karena Indonesia memiliki luas lahan dan agroklimat yang sangat potensial untuk dikembangkan sebagai usaha pertanian. Indonesia juga sejak lama dikenal sebagai penghasil produksi pertanian yang sangat diperlukan dan laku di pasar dunia. Tapi sumbangan sektor pertanian terhadap lapisan tenagaa kerja, pendapatan nasional dan devisa juga masih sangat tinggi. Kontribusii sektor pertanian saat ini sangat berpengaruh untuk pembangunan negara. Hal ini disebabkan oleh beberapa faktor diiantaranya, sektor pertanian merupakan sumber persediaan benda-benda baku yang dibutuhkan oleh suatu negara, meningkatnya pendapatan dari sebagian penduduk menyebabkan kebutuhan juga harus meningkat, adanya kewajiban penyediaan bahan-bahan yang mendukung sektor lain terutama industri. Sector pertanian merupakan dasar dari hubungan pasar yang dapat mencpiptakan sppread - effect dalam proses pembangunan, dan sector pertanian merupakan sumber pendapatan masyarakat di negara berkembanng yang hidup di pedesaan (Mardikanto,2007). Kelapa sawit adalah salah satu produk yang sangat mampu memberikan donasi dalam perekonomian bagi Indonesia yang berasal dari sub-sector perkebunan. Kelapa sawit menjadi tanaman yang menghasilkan minyak sawit dan inti sawit merupakan salah satu unggulan tanamann perkebunan yang menjadi sumber penghasil devisa non migas bagi indonesia. Dengan banyaknya hasil produksi minyak kelapa sawit di Indonesia dalam perdagangan minyak nabati dunia membuat pemerintah untuk memacu kemajuan pengembangan ekspor minyak kelapa sawit.

Menurut Lubis, A.U. (2008), minyak kelapa sawit mempunyai kemampuan daya saing yang sangat cukup kompetitif dibanding minyak nabati lainnya, karena : a) produktivitas perhektar cukup tinggi, b) ditinjau dari aspek gizi, minyak kelapa sawit tidak terbukti jadi penyebab meningkatnya kadar kolesterol, bahkan mengandung beta karoten sebagai provitamin A. Tanaman kelapa sawit menjadi penghasil minyak nabati yang paling banyak yang mempunyai produktifitas yang lebih tinggi dibandingkan dengan tanaman penghasil minyak nabati lainnya.

Menurut Soediyono (2009) Pendapatann adalah hasil yang diterima oleh para anggota masyarakat untuk jangka waktu tertentu sebagai balas jasa atas faktor-faktor produksi yang mereka sumbangkan dalam turut serta membentuk produk nasional.

Pengaruh pengalaman terhadap pendapatan adalah apabila pengalaman semakin lama (meningkat) maka pendapatan juga akan mengalami peningkatan. Karena semakin lama seseorang menekuni pekerjaan tersebut maka pengetahuan atau keahlian akan bertambah di bandingkan dengan orang yang baru bekerja. Pengalaman adalah sejauh mana penguasaan 
seseoraang terhadap bidang ini pekerjaan yang selama yang ditekuninya. Pengalam bekerja seseorang dapat menjadi sebuah keuntungan dalam pemilihan strategi dan cara melakukan pekerjaan nya, dan dapat melakukan pemikiran atu pun ide-ide dalam setiap pekerjaan yang di lakukan. Tenaga kerja yang memiliki pengalaman kerja yang lebih lama akan memiliki ide-ide yang lebih matang dan tepat dalam pekerjaannya. Selain itu, lamanya tenaga kerja menekuni bidang pekerjaannya akan mempengaruhi kemampuan profesionalnya.

Selain pengalaman, pengaruh usia sangatlah penting dalam usaha kelapa sawit terutama pengaruh usia terhadap pendapatan adalah semakin tua seseorang maka semakin berkurang pendapatannya. Kerena di usianya yang semakin bertambah maka tenaganya semakin berkurang, dan seseorang tersebut tidak bisa bekerja dengan waktu yang maksimal. Tuti (2003) pekerja yang lebih mudah cenderung mengalami ketidak berdayaan yang lebih tinggi bila dibandingkan dengan pekerja yang lebih tua. Hal ini dapat terjadi dikarenakan pekerja yang lebih muda cennderung rendah pengalaman kerjanya jika dibandingkan dengan pekerja yang lebih tua, ataupun disebabkan karena faktor lain seperti pekerja yang lebih tua lebih stabil, lebih matang, mempunyai pandangan yang lebih seimbang terhadap kehidupan sehingga tidak mudah mengalami tekanan mental atau ketidak berdayaan dalam pekerjaan.

Selain usia pengaruh waktu kerja juga sangat berhubungan antara waktu kerja dengan pendapatan, semakin lama seseorang bekerja maka semakin tinggi pendapatannya, apa bila seseorang bekerja dalam waktu yang lama otomatis hasil yang diperoleh juga akan terpengaruhi begitu juga dengan sedikitnya jam kerja yang di habiskan oleh seseo rang dalam bekerja. Komaruddin (2006) uraian jam kerja adalah proses untuk menetapkan jumlah jam kerja orang yang digunakan atau dibutuhkan untuk menyelesaikan satu pekerjaan dalam waktu tertentu. Jam kerja merupakan bagian paling umum yang harus ada pada sebuah perusahaan.

Kemudian selain waktu kerja, produksi juga sangat berpengaruh terhadap pendapatan. Hal itu dapat dilihat apa bila semakin banyak produksi yang di peroleh maka semakin banyak juga pendapatan, atau pun sebaliknya semakin sedikit produksi yang di dapatkan maka semakin sedikit juga pendapatan. Produksi adalah penciptaan atau penambahan fae dah, bentuk, waktu dan tempat atas faktor-faktor produksi sehingga lebih bermanfaat bagi pemenuhan kebutuhan manusia. Assauri (2004) istilah produksi dan operasi sering digunakan dalam suatu organisasi yang menghasilkan keluaran atau output, baik yang berupa barang maupun jasa. Secara umum produksi diartikan sebagai suatu kegiatan atau proses yang mentransformasikan masukan (input) menjadi hasil keluaran (output).

Berikut di Kecamatan Ranah Batahan Kabupaten Pasaman Barat dapat dilihat beberapa petani kelapa sawit pada tabel di bawah ini.

\section{Tabel 1.1}

\section{Data Petani Kelapa Sawit Di Kecamatan Ranah Batahan}

Dengan Luas Lahan 0,5 H - 3 H

\begin{tabular}{|c|c|c|c|c|c|}
\hline Nama & $\begin{array}{c}\text { Pendapatan } \\
\text { (Rp) }\end{array}$ & $\begin{array}{c}\text { Pengalaman } \\
\text { (Th) }\end{array}$ & $\begin{array}{c}\text { Usia } \\
\text { (Th) }\end{array}$ & $\begin{array}{c}\text { Waktu } \\
\text { Kerja } \\
\text { (jam) }\end{array}$ & $\begin{array}{c}\text { Produksi } \\
\text { (Kg) }\end{array}$ \\
\hline M.Yunan & 1.650 .000 & 16 & 56 & 8 & 1.500 \\
\hline Safaruddin & 1.540 .000 & 11 & 52 & 6 & 1.400 \\
\hline Sawaluddin & 990.000 & 6 & 47 & 6 & 900 \\
\hline Harmita & 880.000 & 10 & 33 & 7 & 800 \\
\hline Sangkot & 1.470 .000 & 12 & 49 & 8 & 1.400 \\
\hline Ali Aswar & 330.000 & 7 & 43 & 4 & 300 \\
\hline Khoiruddin & 805.000 & 10 & 67 & 5 & 700 \\
\hline Zulfikar & 1.320 .000 & 15 & 38 & 8 & 1.200 \\
\hline M.Saleh & 749.000 & 12 & 51 & 7 & 700 \\
\hline $\begin{array}{c}\text { Henri } \\
\text { Saputra }\end{array}$ & 1.819 .000 & 8 & 38 & 8 & 1.700 \\
\hline Syeprizal & 735.000 & 8 & 29 & 6 & 700 \\
\hline $\begin{array}{c}\text { Hadia } \\
\text { Rifka }\end{array}$ & 802.500 & 9 & 27 & 6 & 750 \\
\hline S.Hamsah & 1.260 .000 & 20 & 60 & 7 & 1.200 \\
\hline
\end{tabular}

(Sumber: Wawancara Tanggal 11 Oktober 2019)

Dari table 1.1 diatas dapat diketahui adanya ketidak sesuaian teori dengan fakta di lapangan hal itu dapat kita lihat antara Bapak Safaruddin dengan Bapak Sangkot. Bapak Safaruddin mempunyai lahan seluas 1,8 Ha mempunyai pengalaman kerja selama 11 tahun dan masa panen 2 minggu sekali kemudian berpenghasilan sebesar.

Rp.1.540.000.00, sedangkan Bapak Sangkot mempunyai lahan seluas 2,1 Ha mempunyai pengalaman kerja selama 12 tahun dan masa panen 3 minggu sekali kemudian berpenghasilan sebesar Rp. 1.470.000.00, dari pernyataan diatas dapat kita ketahui bahwa tidak sesuai dengan teori pengalaman kerja. Seharusnya Bapak Sangkot mendapatkan pendapatan yang lebih besar di bandingkan dengan bapak Safaruddin karena pengalaman bapak sangkot lebih lama dibandingkan dengan bapak Safaruddin, bapak sanggkot memiliki penggalaman kerja selama 12 tahun sedangkan bapak safaruddin 11 tahun akan tetapi 
pendapatanan bapak safaruddin lebih besar di bandingkan denggan bapak sangkot.

Dilihat dari usia seharusnya usia seseorang yang memiliki usia yang lebih tua akan medapatkan penghasilan lebih rendah dibandingkan dengan seseorang yang lebih muda dikarenakan apabila seseorang sudah berusia tua akan mudah lelah dibandingkan dengan seseorang yang lebih muda. Dapat dilihat pada Bapak Ali Aswar dengan Bapak Khoiruddin. Bapak Ali aswar memiliki usia 43 tahun yang memiliki luas lahan $0,7 \mathrm{Ha}$ dan berpendapatan sebesar Rp. 330.000.00, per 2 minggu sekali sedangkan Bapak Khiruddin memiliki usia 67 tahun yang memiliki luas lahan $0,7 \mathrm{Ha}$ dan berpendapatan sebesar Rp.805.000.00, per 2 minggu sekali. Seharusnya pendapatan Bapak Ali Aswar lebih tinggi dari pada Bapak Khoiruddin karena usia Bapak Ali Aswar lebih muda dibandingkan dengan Bapak Khoiruddin.

Waktu kerja merupakan waktu yang dihabiskan oleh seseorang untuk bekerja. Pengaruh waktu kerja terhadap pendapatan adalah semakin lama seseorang bekerja maka semakin tinggi pendapatannya. Akan tetapi yang terjadi di lapangan seperti bapak Khoruddin yang mempunyai waktu kerja selam 5 jam berpenghasilan sebesar Rp.805.000.00, per 2 minggu sekali.

Sedangkan Bapak M. Saleh yang mempunyai jam kerja selama 7 jam dengan penghasilan sebesar Rp.749.000.00, per 2 minggu sekali. Seharusnya Bapak M Saleh berpendapatan lebih tinggi dibandingkan dengan bapak Khoiruddin karena jam kerja bapak M Saleh lebih lama dibandingkan dengan Bapak Khiruddin.

Dilihat dari hasil produksi antar bapak Safaruddin dengan Bapak Sangkot mendapatkan hasil produksi yang sama akan tetapi mempunyai pendapatan yang berbeda dan luas lahan yang berbeda. Untuk hasil produksi yang dihasilkan oleh bapak Sangkot sebesar $1.400 \mathrm{Kg}$ dengan luas lahan seluas 2,1 Ha besar pendapatan sebesar Rp.1.470.000.00, sedangkan hasil produksi yang di hasilkan oleh bapak Safaruddin sebesar $1.400 \mathrm{Kg}$ dengan luas lahan seluas 1,8 Ha besar pendapatan sebeasar Rp.1.540.000.00. Seharusnya Hasil Produksi antara bapak Sangkot dengan Bapak Safaruddin berbeda di karenakan luas lahan yang dimilikipun berbeda dan seharusnya juga pendapa tan yang dihasikan sama besar dikarenakan mendapatkan hasil produksi yang sama yaitu samasama mendapatkan hasil produksi sebesar $1.400 \mathrm{Kg}$.

Kelapa sawit adalah pohon industri/ perkebunan yang berguna sebagai penghasiil minyak industri minyak masak, maupun bahan bakar. Pohon Kelapa Sawit terdiri dari dua jenis yaitu elaeis guinensis dan elaeis oleifera yang digunakan untuk pertanian komersil dalam pengeluaran minyak kelapa sawit. Pohon Kelapa Sawit elaeis guineensis, berasal dari Afrika barat diantara Angola dan Gambia, pohon kelapa sawit elaeis oleifera, berasal dari Amerika tengah dan Amerika selatan. Kelapa sawit menjadi global setelah revolusi industri pada akhir abad ke-19 yang menyebabkan tingginya permintaan minyak nabati untuk industri sabun dan bahan pangan (Dinas Perkebunan Indonesia, 2007).

Berdasarkan uraian diatas maka dari itu penulis tertarik meneliti tentang

\section{Faktor-Faktor Yang Mempengaruhi Pendapatan Petani Kelapa Sawit Di Kecamatan Ranah Batahan Kabupaten Pasaman Barat.}

\section{Rumusan Masalah}

Berdasarkan uraian pada latar belakang, maka Rumusan Masalah yang akan dikaji pada penelitian ini yaitu:

1. Berapa besarkah pengaruh pengalaman kerja terhadap pendapatan petani kelapa sawit di Kecamatan Ranah Batahan Kabupaten Pasaman Barat?

2. Berapa besarkah pengaruh usia kerja terhadap pendapatan petani kelapa sawit di Kecamatan Ranah Batahan Kabupaten Pasaman Barat?

3. Berapa besarkah pengaruh waktu kerja terhadap pendapatan petani kelapa sawit di Kecamatan Ranah Batahan Kabupaten Pasaman Barat?

4. Berapa besarkah pengaruh Produksi terhadap pendapatan petani Kelapa Sawit di Kecamatan Ranah Batahan Kabupaten Pasaman Barat?

\section{Tujuan Penelitian}

Berdasarkan uraian pada latar belakang, maka Rumusan Masalah yang akan dikaji pada penelitian ini yaitu:

1. Mengetahui pengaruh pengalaman kerja terhadap pendapatan petani kelapa sawit di Kecamatan Ranah Batahan Kabupaten Pasaman Barat.

2. Mengetahui pengaruh usia kerja terhadap pendapatan petani kelapa sawit di Kecamatan Ranah Batahan Kabupaten Pasaman Barat.

3. Mengetahui pengaruh waktu kerja terhadap pendapatan petani kelapa sawit di Kecamatan Ranah Batahan Kabupaten Pasaman Barat.

4. Mengetahui pengaruh Produksi terhadap pendapatan petani Kelapa Sawit di Kecamatan Ranah Batahan Kabupaten Pasaman Barat. 


\section{Manfaat Penelitian}

Hasil dari penelitian ini diharapkan dapat memberikan manfaat atau kontribusi terkait seperti:

1. Praktis.

a) Masyarakat, diharapkan bagi masyarakat petani kelapa sawit dapat mengetahui faktor-faktor penyebab rendahnya hasil produksi panen kelapa sawit sehingga hasil yang di dapatkan maksimal.

b) Pemerintah, bagi pemerintah supaya bisa menstabilkan harga kelapa sawait supaya petani kelapa sawit bisa berpendapatan sesuai dengan hasil produksi.

2. Akademis

a) Penulis, sebagai penambah wawasan penge tahuan dan wawasan di bidang pertanian kelapa sawit dan mengetahui fak tor-faktor yang mempengaruhi pendapa tan petani kelapa sawit.

b) Referensi, sebagai tanbahan referensi baca an tentang kelapa sawit di perpusta kaan.

c) Peneliti Selanjutnya, dapat menambah varia bel penelitian terkait dengan penelitian yang penulis teliti sebagai penelitian terda hu.

\section{TINJAUAN PUSTAKA \\ Pendapatan}

Soediyono (2009) Pendapataan adalah jumlah yang diterima para anggota masyarakat untuk jangka waktu tertentu sebagai balas jasa atas faktor-faktor produksi yang mereka sumbangkan dalam turut serta membentuk produk nasional. Reksoprayitno dalam Mahyu (2013) mendefinisikan pendapatan sebagai total penerimaan yang diperoleh pada waktu tertentu. Milfitra (2016) Pendapatan adalah tingkat pendapatan petani secara umum di pengaruhi beberapa komponen yaitu jumlah produksi, harga jual, dan biaya-biaya produksi.

\section{Pengalaman Kerja}

Almutahar (2014) Pengalaman kerjaa adalah lamanya seseorang melaksanakan pekerjaan dan sesuai dengan kemampuannya. Dari pendapat terse but dapat diambil kesimpulan bahwa pengalaman kerja adalah waktu yang digunakan oleh seseorang untuk memperoleh pengetahuan, keterampilan, dan sikap sesuai dengan pekerjaan dan jenis tugasnya.

Manulang Pengalaman kerja adalah tingkat penguasaan pengetahuan serta keterampilan tentang metode suatu pekerjaan karena keterlibatan karyawan tersebut dalam pelaksanaan tugas pekerjaan. Pendapat lain Ranupandojo mengemukakan pengalaman kerja adalah jangka waktu atau masa kerja yang telah dijalani seseorang dapat memahami tugas tugas suatu pekerjaan dan telah melaksanakan dengan baik. Menurut Trijoko, pengalaman kerja adalah pengetahu an atau keterampilan yang telah di tekuni dan di kuasai seseorang atau pekerjaan yang telah dilakukan selama beberapa waktu tertentu (Ismanto, 2005).

\section{Usia Kerja}

Tuti (2003) pekerja yang lebih muda cenderung mengalami ketidak berdayaan yang lebih tinggi bila dibandingkan dengan pekerja yang lebih tua. Hal ini dapat terjadi karna pekerja yang lebih muda cenderung lebih rendah pengalaman kerjanya jika di bandingkan dengan pekerja yang lebih tua, atau pun di sebabkan karena faktor lain seperti pekerja yang lebih tua lebih normal, lebih matang, mempunyai pandangan yang lebih seimbang terhadap kehidupan sehingga tidak mudah mengalami tekanan mental atau ketidak berdayaan dalam pekerjaan.

Payaman J. Simanjuntak Tenaga kerja adalah penduduk dengan batas umur minimal 10 tahun tanpa batas maksimal. Dengan demikian, tenaga kerja di Indonesia yang dimaksudkan adalah penduduk yang berumur 10 tahun atau lebih, sedangkan yang berumur di bawah 10 tahun sebagai batas minimum. Ini berdasarkan kenyataan bahwa dalam umur tersebut sudah banyak penduduk yang berumur muda yang sudah bekerja dan mencari pekerjaan. Sedangkan tenaga kerja terdidik adalah tenaga kerja yang memiliki pendidikan cukup tinggi dan ahli dalam bidang tertentu (Setiawan, 2010).

\section{Waktu Kerja}

Waktu kerja adalah waktu seseorang melakukan pekerjaan yang dapat dilaksanakan siang hari atau malam hari. Menyiapka pekerjaan-pekerjaan yang akan di laksanakan dimasa yang akan datang merrupakan langkah-langkah memperbaiiki waktu atau melakukan manajemen waktu. Seumpama perencanaan pekerjaan belum dibuat dengan teliti, tidak akan ada yang dapat dijadikan panduan untuk menentukan bahwa usaha yang dijalankan adalah sebanding dengan sasaran yang ingin dicapai. Dengan adanya pengelolaan kegiatan-kegiatan yang akan dibuat, sesorang itu dapat menghematt waktu dan kerjanya Su'ud, (2007).

\section{Produksi}

Produksi adalah penciptaan atau penambahan faedah, bentuk, waktu dan tempat atas faktor-faktor produksi sehingga lebih bermanfaat bagi pemenuhan 
kebutuhan manusia. Assauri (2004) istilah produksi dan operasi sering digunakan dalam suatu organisasi yang menghasilkan pengeluaran atau output, baik yang berupa barang maupun jasa. Secaara global produksi diartikan sebagai suatu kegiatan atau proses yang metamorfosis masukaan (input) menjadi hasil pengeluaran (output).

\section{Karangka Konseptual}

Berdasarkan penjelasan teori dan konsep sebelumnya maka dapat di gambarkan karangka konseptual penelitian berfikir sebagai berikut:

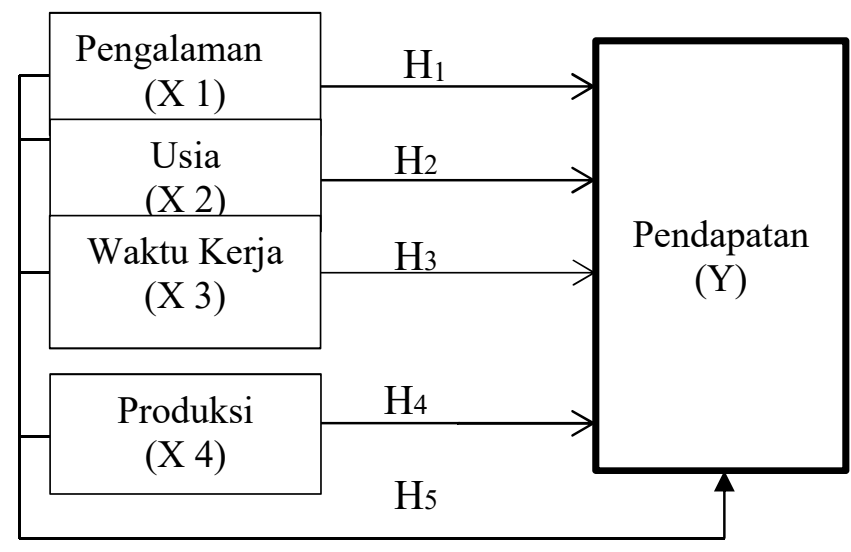

(Gambar 2.1) Karangka konseptual berpikir

Gambar 2.1 diatas menjelaskan bahwa pengalaman, usia, waktu kerja, dan produksi merupakan variabel independen yang akan di uji secara parsial dan simultan. Pengujian secara parsial merupakan sebuah pengujian yang bersifat pribadi antara variabel $\mathrm{x} 1$ atau pengalaman, $\mathrm{x} 2$ atau usia, $\mathrm{x} 3$ atau waktu kerja, $\mathrm{x} 4$ atau produksi. Dari variabel independen tersebut di uji kepada variabel dependen. Sedangkan uji F di gunakan untuk menguji secara simultan atau secara bersama-sama antara variabel $\mathrm{x} 1, \mathrm{x} 2, \mathrm{x} 3$, dan $\mathrm{x} 4$ terhadap pendapatan atau $\mathrm{Y}$.

\section{Hipotesis Penelitian}

Berdasarkan cakupan beberapa teori menyang kut tentang pengalaman, usia, waktu kerja, produksi terhadap pendapatan dari responden adalah masyarakat di Kecamatan Ranah Batahan Kabupaten Pasaman Barat di rumuskan hipotesis penelitian sebagai berikut:

$\mathrm{H}_{1}$ : Diduga pengalaman berpengaruh positif dan signifikan terhadap pendapatan petani kelapa sawit di Kecamatatan Ranah Batahan Kabupaten Pasaman Barat.

$\mathrm{H}_{2}$ : Didugausia berpengaruh negatif dan signify kan terhadap pendapatan petani kelapa sawit di Kecamatatan Ranah Batahan Kabupaten Pasaman Barat.
$\mathrm{H}_{3}$ : Diduga waktu kerja berpengaruh positif dan signifikan terhadap pendapatan petani kelapa sawit di Kecamatatan Ranah Batahan Kabupa ten Pasaman Barat.

$\mathrm{H}_{4}$ : Diduga Produksi berpengaruh positif dan signifikan terhadap pendapatan petani sawit di Kecamatatan Ranah Batahan Kabupaten Pasaman Barat.

$\mathrm{H}_{5}$ : Diduga pengalaman, usia, waktu kerja dan produksi berpengaruh positif dan signifikan terhadap pendapatan petani kelapa sawit di Kecamatatan Ranah Batahan Kabupaten Pasaman Barat.

\section{METODE PENELITIAN}

\section{Objek Dan Lokasi Penelitian}

Objek penelitian dari penelitian ini adalah pengalaman, usia, waktu kerja, produksi dan pendapatan. Lokasi dalam penelitian di Kecamatan Ranah Batahan Kabupaten Pasaman Barat.

\section{Jenis Dan Sumber Data}

Sumber data adalah segala sesuatu yang dapat memberikan informasi mengenai data.Soediyono (2009) berdasarkan sumbernya, data dibedakan menjadi dua, yaitu data primer dan data sekunder.

1. Data primer

Data Primer yaitu data yang dibuat oleh peneliti untuk menyelesaikan tugas atau permasalahan yang sedang ditanganinya. Data di kumpulkan sendiri oleh peneliti langsung dari sumber pertama atau tempat objek penelitian dilakukan.

2. Data sekunder

Data Sekunder yaitu data yang telah di kumpulkan untuk maksut selain menyelesaikan masalah yang sedang dihadapi. Data ini dapat ditemukan dengan mudah. Dalam penelitian ini yang menjadi sumber data sekunder dalah literatur, artikel, jurnal dan Badan Pusat Statistik (BPS) Kabupaten Pasaman Barat yang berkenaan dengan penelitian yang dilakukan.

\section{Populasi dan Sampel Populasi}

Menurut (Soediyono, 2009) populasi adalah suatu wilayah yang terdiri dari objek/subjek yang memiliki perlengkapan atau keistimewaan khusus yang di tetepkan oleh seseorang ilmuan yang di pelajari dan 
untuk mengambil berjumlah 5.473 orang petani kelapa sawit. (BPS, 2018).

\section{Sampel}

Menurut (Jugiyanto, 2011), Sampel adalah suatu bagian dari komunitas yang di ambil melalui cara tertentu yang di anggap bisa mewakili populasi. Ukuran sampel dapat di hitung dengan rumus Slovin, yaitu:

$$
\begin{aligned}
& \mathrm{n}=\frac{N}{1+N(e)^{2}} \\
& \text { Keterangan : } \\
& \mathrm{n}=\text { ukuran / besarnya sampel } \\
& \mathrm{N}=\text { ukuran / populasi } \\
& \mathrm{e}=\text { Toleransi kesalahan(error tolerance) } 10 \% \\
& \mathrm{n}=\frac{5.473}{1+5.473(0,1)^{2}} \\
& \mathrm{n}=\frac{5.473}{55,73} \\
& \mathrm{n}=98,2
\end{aligned}
$$

Berdasarkan rumus diatas maka jumlah sampel dalam penelitian yang akan diteliti berjumlah 98 Orang.

\section{Teknik Pengumpulan Data}

\section{Wawancara (interview)}

Wawancara merupakan pengumpulan data denagan cara mengajukan pertanyaan kepada masyarakat yang telah ditentukan sebelumnya untuk mendapatkan hasil wawancara. Menurut Esterberg dalam Soediyono (2009) wawancara adalah pertemuan dua orang untuk bertukar informasi dan ide melalui Tanya jawab, sehingga dapat dikonstruksikan makna dalam suatu topik tertentu.

\section{Kusioner}

Kuisioner adalah kegiatan yang di lakukan untuk kegiatan pengumpulan data melalui daftar pertanyan yang di berikan kepada petani sawit di Kecamatan Ranah Batahan Kabupaten Pasaman Barat.

\section{Definisi Operasional Variabel}

Berdasarkan rumusan masalah dan hipotesis penelitian, variabel penelitian terdiri dari lima variabel, $\mathrm{X}$ sebagai independen dan variabel $\mathrm{Y}$ sebagai sebagai variabel dependen. Adapun variabelnya meliputi:

a. Pendapatan Log (Y) adalah penerimaan petani sawit dari hasil produksi di kali dengan harga. Satuannya Rupiah. b. Pengalaman Kerja $\left(\mathrm{X}_{1}\right)$ adalah lamanya petani melaksanakan pekerjaan bertani sawit. Satuannya Tahun.

c. Usia $\left(\mathrm{X}_{2}\right)$ adalah lama hidup seseorang. Satuannya Tahun

d. Waktu Kerja $\left(\mathrm{X}_{3}\right)$ adalah Waktu yang di pergunakan oleh seseorang dalam bekerja di kebun sawit. Satuannya Jam.

e. Produksi $\log \left(\mathrm{X}_{4}\right)$ adalah suatu kegiatan yang memproses berbagai faktor produksi (input) menjadi barang lain (output) yang mempunyai daya guna dan hasil guna yang lebih besar dari semula. Satuannya Kg.

\section{Metode Analisis Data \\ Analisis Regresi Linear Berganda}

Data yang diperoleh dari sumber data, dan kemudian ditabulasi dan diolah dengan menggunakan rumus persentase yang berguna untuk melihat kecenderungan-kecenderungan indikator masingmasing indikator. Selanjutnya untuk mengukur besar dampak dari variabel-variabel, dan data di analisis dengan menggunakan persamaan regresi linier berganda. Soediyono (2009).

$\log \mathrm{Y}=\mathrm{a}+\mathrm{b}_{1} \mathrm{X}_{1}+\mathrm{b}_{2} \mathrm{X}_{2}+\mathrm{b}_{3} \mathrm{X}_{3}+\log \mathrm{b}_{4} \mathrm{X}_{4}+\mathrm{b}_{5} \mathrm{X}_{5}+e i$ Dimana :

$\log \mathrm{Y}=$ pendapatan

$\mathrm{X}_{1}=$ pengalaman

$\mathrm{X}_{2}=$ usia

$\mathrm{X}_{3}=$ waktu kerja

$\log \mathrm{X}_{4}=$ produksi

$\mathrm{a}=$ konstanta

$\mathrm{b}=$ koefesien yang di cari

$e=$ Standar Error (residual)

Untuk mengukur pengaruh antar variabel digunakan beberapa langkah pengujian.Yaitu pengujian asumsi klasik dan pengujian statistik.

\section{Uji Normalitas}

Dalam buku Winarno (2009) Salah satu asumsi dalam analisis statistika adalah data berdistribusi normal. Dalam analisis multivariat, para peneliti menggunakan pedoman kalau tiap variabel terdiri atas 30 data, maka data sudah berdisribusi normal. Untuk menguji dengan lebih akurat, diperlukan alat analisis dan eviews menggunakan dua cara, yaitu dengan histogram dan uji Jarque-Bera.

Jarque-Bera adalah uji statistik untuk mengetahui apakah data distribusi normal. Uji mengukur skewess dan kurtosisdata dan dibandingkan dengan dibandingkan dengan apabila datanya bersifat normal.

Lebih mudah bila melihat koefisien jarqueBeradan probilitasnya.Kedua angka ini bersifat saling 
mendukung.

1. Bila J-B tdak signifikan (lebih kecil dari 2), maka data berdistribusi normal

2. Bila probilitasnya lebih besar dari 5\% (bila anda menggunakan tingkat signifi kan tersebut), maka data berdistribusi normal (hipotesis nolnya adalah data berdistribisi normal).

\section{Uji Asumsi Klasik}

Uji asumsi klasik yang digunakan dalam penelitian ini adalah uji autokorelasi, multikolinearitas dan heteroskedastitas.

\section{a. Uji Multikolinearitas}

Data buku eviews Winarno (2009) mengemuka kan bahwa multikolinearitas adalah kondisi adanya hubungan linier antara variabel independen.Uji multikolinieritas adalah situasi adanya korelasi variabel-variabel bebas diantara satu dengan yang lain.Uji multikolinearitas adalah salah satu pengujian di dalam asumsi klasik yang berguna untuk melihat apakah variabel-variabel indepeden di dalam penelitian memiliki hubungan atau tidak. (Gujarati, 2012) mengatakan bahwa model regresi linear berganda yang baik tidak memiliki hubungan di antara variabel-variabel bebasnya.Uji multikolinieritas dapat dilihat melalui nilai $r$ korelasi. Tidak terjadi multikolinieritas apabila nilai r korelasi di dibawah 0,8 .

\section{b. Uji Heteroskedastisitas}

Menurut winarno (2009) Heteroskedastisitas adalah keadaan dimana faktor gangguan tidak memiliki varian yang sama. Heteroskedastisitas merupakan suatu fenomena dimana estimator regresi bias, namun varian tidak efisien (semakin besar populasi atau sampel, maka semakin besar farina). Uji Heteroskedastisitas bertujuan untuk menguji apakah dalam model regresi terjadi ketidak samaan farina dari residual satu pengalaman kepengamatan yang lain. Jika farina residual satu pengamatan kepengamatan yang lain tetap, maka disebut homoskedasitas dan jika berbeda disebut heteroskedastisitas.

Uji White (Wehite test). Pengujian terhadap Heteroskedastisitas dapat dilakukan dengan melakukan wehite test yaitu dengan cara meregresi residual kuadrat dengan variabel bebas, variabel bebas kuadrat dengan perkalian variabel bebas. Ini dilakukan dengan membandingkan $\mathrm{X}^{2}$ hitung dengan $X^{2}$ tabel, apabila $X^{2}$ hitung $>X^{2}$ tabel maka hipotesis yang mengatakan bahwa terjadi Heteroskedastisitas diterima, dan sebaliknya apabila $\mathrm{X}^{2}{ }_{\text {hitung }}<\mathrm{X}^{2}$ tabelmaka hipotesis yang mengatakan bahwa terjadi Heteroskedastisitas ditolak. Dalam metode White selain menggunakan nial $\mathrm{X}^{2}$ hitung, untuk memutuskan apakah data terkena Heteroskedastisitas, dapat digunakan niai probababilitas Chi-Square yang merupakan niali probabilitas uji white. Jika probabilitas Chi-Square $>$ a berarti Ho ditolak jika probabilitas Chi-Square< a berarti Ho diterima.

\section{Pengujian Hipotesis}

Menurut Silalahi (2012) menyatakan hipotesis merupakan tive proporsi yang langsung dapat diuji. Oleh karena itu hipotesis selalu mengambil bentuk atau dinyatakan dalam kalimat pernyataan dan dalam pernyataan ini secara umum dihubungkan satu lebih variabel dengan satu variabel lain. Berdasarkan dari penelitian-penelitian lainnya, serta mengacu pada hipotesis teori, maka dalam penelitian ini penelitian merumuskan hipotesis nol (Ho) dan hipotesis alternating ( $\mathrm{Ha})$ yang kemudian akan dilakukan pengujian atas hipotesis nol (Ho) tersebut untuk membuktikan apakah hipotesis nol (Ho) tersebut ditolak atau gagal di tolak. Untuk menguji siknifikansi model digunakan Uji T-test, Uji F-test, Koefisien Korelaso (R), dan Koefisien Determinasi $\left(\mathrm{R}^{2}\right)$.

\section{a. Uji Regresi Parsial (Uji-t)}

Uji statistic $t$ ini pada dasarnya dilakukan bertujuan untuk menunjukkan seberapa jauh pengaruh satu fariabel penjelas atau independen secara individual dalam menerangkan variasi dependen Gehozali,(2012). Cara melakukan uji t adalah dengan membandingkan $t$ hitung dengan $t$ tabel pada derajat kepercayaan $5 \%$ atau 0,05 . Pada pengujian secara persial atau uji $\mathrm{t}$ ini menggunakan uji dua sisi pada $\alpha$ $5 \%$, maka t $2=0,025$ dengan menggunakan kriteria Ho: $\beta=0$ artinya tidak ada pengaruh siknifikan antara fariabel independen terhadap variabel dependen. Ha: $\beta \neq 0$ artinya ada pengaruh siknifikan antara variabel independen terhadap variabel dependen. Jika $t$ hitung lebih kecil dari t tabel maka Ho diterima dan Ha ditolak.Dan begitu juga sebaliknya jika t hitung lebih besar dari pada $\mathrm{t}$ tabel maka Ho ditolak dan Ha diterima.

\section{b. Uji Regresi Simultan (Uji-f)}

Pengujian statistik $\mathrm{f}$ ini pada dasarnyta bertujuan untuk menunjukkan apakah semua variabel independen atau bebas dimasukkan dalam model mempunya pengaruh secara bersama-sama terhadap variabel dependen atau terikat Ghozali, (2005). Pengujian pada regresi secara simultan atau 
menyeluruh dapat dilakukan dengan distribusi $\mathrm{F}$ (ftest) atau "Fisher Test" dengan degreeof freedom (derajat kebebasan) k-1 dan n-k, dimana k adalah jumlah variabel dan $\mathrm{n}$ adalah jumlah data atau observasi (Supranto,2001). Jika nialai siknifikansi lebih besar dari 5\% maka hipotesis ditolak (koevisien regresi tidak siknifikan), artinya secara simultan variabel-variabel independen atau bebas tidak ada pengaruh yang siknifikan terhadap variabel dependen atau terikat. Jika nilai siknifikan lebih kecil dari 5\% maka hipotesisi diterima (koefisien regresi siknifikan).Hal ini berarti bahwa secara simultan variabel-variabel independen atau bebas mempunyai pengaruh yang signifikan terhadap variabel dependen atau terikat.

\section{c. Koefesien Korelasi (R)}

Menurut suparto (2014) mengenai analisis korelasi yaitu merupakan suatu cara untuk menetahui kuat atau tidaknya hubungan antara $\mathrm{x}$ dan y apabila dapat dinyatakan dengan fungsi linier (paling tidak mendekati) dan di ukur dengan suatu nilai yang disebut koefisien korelasi. Koefisien korelasi dapat dinyatakan dengan rumus sebagai berikut.

$$
\begin{aligned}
& \mathrm{r}=\frac{n\left(\sum x y\right)-\left(\sum X\right)\left(\sum Y\right)}{\sqrt{\left\{n\left(\sum x^{2}\right)-\left(\sum x\right)^{2}\right\}\left\{n\left(\sum y^{2}\right)-\left(\sum y\right)^{2}\right\}}} \\
& \text { keterangan } \\
& \mathrm{n}=\text { jumlah data } \\
& \mathrm{r}=\text { koefisien korelasi }
\end{aligned}
$$

Untuk dapat memberi interprestasi seberapa kuat hubungan itu, maka dapat dingunakan pedoman seperti yang tertera pada tabel berikut:

Tabel 3.1

Tingkat keeratan antara variabel bebas dengan dengan variabel terkait:

\begin{tabular}{|l|l|}
\hline \multicolumn{1}{|c|}{ Nilai korelasi } & \multicolumn{1}{|c|}{ Interprestasi } \\
\hline Kurang dari 0,20 & $\begin{array}{l}\text { Hubungan rendah sekali / } \\
\text { lemah sekali }\end{array}$ \\
\hline $0,20-0,40$ & $\begin{array}{l}\text { Hubungan rendah tapi } \\
\text { pasti }\end{array}$ \\
\hline $0,40-0,70$ & Hubungan cukup berarti \\
\hline
\end{tabular}

\begin{tabular}{|l|l|}
\hline $0,70-0,90$ & Hubungan tinggi dan kuat \\
\hline Lebih dari 0,90 & $\begin{array}{l}\text { Hubungan tinggi dan kuat } \\
\text { sekali }\end{array}$ \\
\hline
\end{tabular}

Sumber: Subana (2000)

\section{d. Determinasi $\left(\mathbf{R}^{2}\right)$}

Menurut Soediyono (2009) mengenai koefisien determinasi yaitu merupakan suatu ukuran yang menunjukkan besar ragam naik turunnya $\mathrm{Y}$ yang terangkan oleh pengaruhlinier $\mathrm{X}$. hasil dari analisis ini dinyatakan dalam presentasi batas-batas determinasi sebagai berikut.

$$
0<\mathrm{r}^{2}<1
$$

Untuk mengetahui nilai koefisien determinasi, maka dapat dihitung dengan cara mengkuadratkan nilai koefisien korelasi $\left(\mathrm{r}^{2}\right)$. Analisis data ini dilakukan secara kualitatif dengan menggunakan teknik analisis koefisien, determinasi untuk mempelajri bentuk hubungan antara variabel $\mathrm{X}$ dengan variabel $\mathrm{Y}$.

$$
d=r^{2} \times 100 \%
$$
dimana:

$$
\begin{aligned}
& \mathrm{d}=\text { koefisien determinasi } \\
& \mathrm{r}=\text { koefisien korelasi }
\end{aligned}
$$

\section{HASIL PENELITIAN DAN PEMBAHASAN}

\section{Hasil Penelitian \\ Uji Normalitas}

Uji normalitas data dilakukan untuk melihat apakah dalam model regresi, variabel devenden dan variabel indevendennya memiliki distribusi normal atau tidak (Ikhsan, dkk, 2014). Pengujian ini dimasudkan untuk mengetahui apakah dalam model regresi variabel pengganggu atau residual mempunyai distribusi normal. Keputusan terdistribusi normal tidaknya residual secara sederhana dengan membandingkan nilai Probabilitas JB (Jarque-Bera) hitung dengan tingkat alpha 0,05 (5\%). Apabila Prob. JB hitung lebih besar dari 0,05 maka dapat disimpulkan baahwa residual berdistribusi normal.

Berikut adalah hasil uji normalitas yang diperoleh dari program Eviews 9 dapat dilihat pada gambar 4.1 berikut ini: 


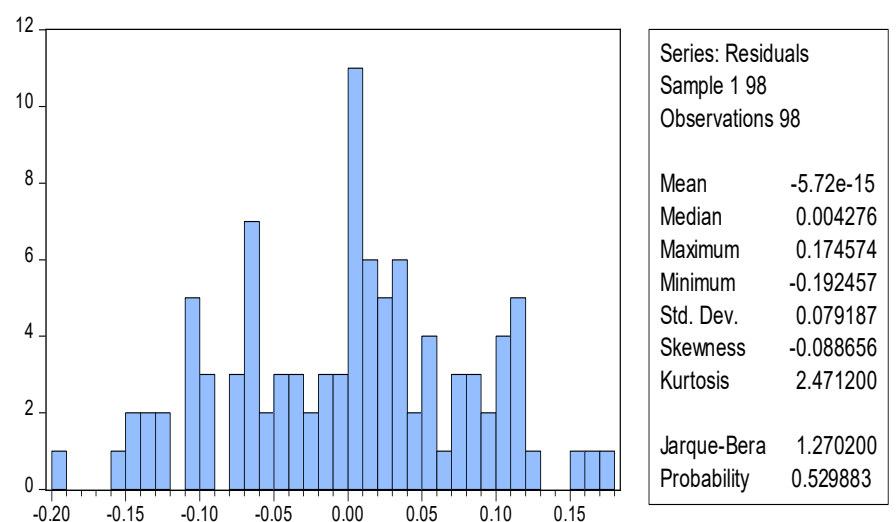

Sumber : Hasil Eviews, data diolah (2021)

Dari gambar 4.1 diatas dapat dilihat bahwa grafik histrogram dapat membentuk pola distribusi simetris, dengan demikian maka dinyatakan residual terdistribusi normal. Hasil dari uji normalitas menunjukkan bahwa nilai Prob JB $>0,05$ yaitu sebesar 0,529>0,05 maka dapat disimpulkan bahwa residual berdistribusi normal.

\section{Uji Asumsi Klasik}

\section{Uji Multikolinieritas}

Multikolinieritas berhubungan dengan situasi dimana ada hubungan linier baik yang pasti atau mendekati pasti diantara variabel independen (Gujarati, 2003). Multikolinieritas ini bertujuan untuk mengetahui apakah masing-masing variabel bebas saling berhubungan secara linier dalam model persamaan regresi yang digunakan. Hasil uji Multikolinieritas dapat dilihat pada Tabel Berikut ini

Tabel 4.1

\section{Hasil Uji Multikolinieritas}

\begin{tabular}{|l|c|c|c|c|l|}
\hline & Pendapatan & Pengalaman & Usia & $\begin{array}{c}\text { Waktu } \\
\text { Kerja }\end{array}$ & Produksi \\
\hline Pendapatan & 1 & 0.6559 & -0.0285 & 0.7605 & 0.7686 \\
\hline Pengalaman & 0.6559 & 1 & 0.1290 & 0.4496 & 0.4437 \\
\hline Usia & -0.0285 & 0.1290 & 1 & 0.0838 & -0.0736 \\
\hline Waktu_Kerja & 0.7605 & 0.4496 & 0.0838 & 1 & 0.5495 \\
\hline Produksi & 0.7686 & 0.4437 & -0.0736 & 0.5495 & 1 \\
\hline
\end{tabular}

Sumber : Hasil eviews,(2021)

Berdasarkan Tabel 4.1 di atas maka dapat disimpulkan bahwa hasil penelitian ini menunjukkan tidak ada korelasi antar variabel dalam penelitian atau tidak ada multikoliniritas dalam penelitian ini, hal ini dibuktikan oleh nilai korelasi masing-masing variabel berada di bawah 0,8 .

\section{Uji Heteroskedastisitas}

Heteroskedastisitas terjadi pada saat residual dan nilai prediksi memiliki korelasi atau pola hubungan.Untuk mendeteksi ada tidaknya heteroskedastisita maka dengan membandingkan nilai $\mathrm{R}$-squared dan tabel chi-square.

a. Jika nilai Obs*R-squared $>$ chi-square tabel, maka tidak lolos dari uji heteroskedastisitas.

b. Jika nilai Obs*R-squared $<$ chi-square tabel, maka lolos dari uji heteroskedastisitas.

Tabel 4.2

Hasil Uji Heteroskedastisitas

White

F-statistic

1.274639 Prob. F(14,83)

0.2408

Obs*R-squared

17.34152 Prob. Chi-Square(14)

0.2384

Scaled explained SS

11.48795 Prob. Chi-Square(14)

0.6473

$\overline{\text { Sumber : Data diolah, (2021) }}$

Dari hasi table 4.2 di atas dapat dilihat bahwa nilai probabilitas obs* R-square sebesar 0,238, hal ini menunjukkan bahwa tidak terjadi heteroskedastisitas karena probabilitas Chi-Squared sebesar 0,238, nilai tersebut $0,238>0,05$.

\section{Analisis Regresi Linier Berganda}

Uji regresi ini bertujuan untuk mengetahui bagaimana pengaruh variabel-variabel independen (pengalaman kerja, usia, waktu kerja dan produksi) terhadap variabel dependen yaitu pendapatan. Berdasarkan dari hasil Uji analisis regresi linier berganda dengan alat bantu komputer yang menggunakan program Eviesw 8, dapat dilihat pada Tabel sebagai berikut :

Tabel 4.3

Hasil Analisis Regresi Linier Berganda

Dependent Variable: $\log (\mathrm{Y})$

Method: Least Squares

Included observations: 98

\begin{tabular}{lrlrr}
\hline \hline Variable & Coefficient & Std. Error & t-Statistic & \multicolumn{2}{l}{ Prob. } \\
\hline \hline & & & & \\
\multicolumn{1}{c}{ C } & 7.316136 & 0.117500 & 62.26477 & 0.0000 \\
X1 & 0.003613 & 0.001544 & 2.339778 & 0.0214 \\
X2 & -0.001805 & 0.000719 & -2.511795 & 0.0137 \\
X3 & 0.007995 & 0.003953 & 2.022407 & 0.0460 \\
Log(X4) & 0.994276 & 0.018714 & 53.13131 & 0.0000 \\
\hline \hline & & & \\
R-squared & 0.986757 & Mean dependent var & 14.03702 \\
Adjusted R-squared & 0.986187 & S.D. dependent var & 0.688108 \\
S.E. of regression & 0.080872 & Akaike info criterion & -2.142225 \\
Sum squared resid & 0.608246 & Schwarz criterion & -2.010339 \\
Log likelihood & 109.9690 & Hannan-Quinn criter. & -2.088880 \\
F-statistic & 1732.362 & Durbin-Watson stat & 0.983162 \\
Prob(F-statistic) & 0.000000 & &
\end{tabular}

Sumber : Eviews 8, data diolah (2021)

Dari table 4.3 di atas maka model regresi linier berganda adalah sebagai berikut :

$\log \mathrm{Y}=7,316+0,003 \mathrm{X}_{1}-0.001 \mathrm{X}_{2}+0.007 \mathrm{X}_{3}+$ $0.994 \log X_{4}$ 
Dari hasil diatas dapat di interpretasi hasil analisis regresi linier berganda yaitu sebagai berikut

1. Constanta sebesar 7.316 menunjukkan apabila variabel pengalaman usaha, usia, waktu kerja dan produksi bernilai konstan maka variabel dependen pendapatan mempunyainilai sebesar $7,316 \%$.

2. Koefisien variabel pegalaman kerja mempunyai nilai sebesar 0,003. Hal ini menunjukkan hubungan yang positif antara pengalaman kerja dengan pendapatan. Artinya apabila pengalaman kerja mengalami peningkatan 1 tahun maka pendapatanakan mengalami peningkatan sebesar $0.003 \%$

3. Koefisien variabel usia mempunyai nilai sebesar 0,001 . Hal ini menunjukkan hubungan yang negatif antara usia dengan pendapatan. Artinya apabila usia mengalami peningkatan 1 tahun maka pendapatan akan mengalami penurunan sebesar $0.001 \%$.

4. Koefisien variabel waktu kerja mempunyai nilai sebesar 0,007. Hal ini menunjukkan hubungan yang positif antara waktu kerja dengan pendapatan. Artinya apabila waktu kerja mengalami peningkatan 1 jam maka pendapatanakan mengalami peningkatan sebesar $0.007 \%$

5. Koefisien variabel produksi mempunyai nilai sebesar 0,994. Hal ini menunjukkan hubungan yang positif antara produksi dengan pendapatan. Artinya apabila produksi mengalami peningkatan $1 \%$ maka pendapatan akan mengalami peningkatan sebesar $0.994 \%$.

\section{Pengujian Hipotesis \\ Hasil Uji Parsial}

Penelitian ini menggunakan uji $t$ sebagai pengujian hipotesis.Uji t digunakan untuk melihat pengaruh variabel indevenden terhadap variabel dependen secara parsial. Adapun kriteria pengambilan keputusannya yaitu dengan melihat nilai $t$ hitung dengan membandingkannya dengan nilai $t_{\text {tabel }}$ kemudian juga melihat nilai signifikansinya. Adapun hasil pengujian hipotesis di dalam penelitian ini adalah sebagai berikut:

1. Secara parsial pengalaman kerja berpengaruh positif dan signifikan terhadap pendapatan. Hal ini ditunjukkan oleh hasil nilai $\mathrm{t}$ hitung $>\mathrm{t}$ tabel yakni 2,339>1,661 dan nilai signifikan sebesar $0.021<0.05$. Dengan demikian penelitian ini menerima $\mathrm{H}_{1}$.
2. Secara parsial usia berpengaruh negatif dan signifikan terhadap pendapatan. Hal ini ditunjukkan oleh hasil nilai $\mathrm{t}$ hitung $>\mathrm{t}$ tabel yakni 2,511>1,661 dan nilai signifikan sebesar $0.013<$ 0.05 . Dengan demikian penelitian ini menerima $\mathrm{H}_{2}$.

3. Secara parsial waktu kerja berpengaruh positif dan signifikan terhadap pendapatan. Hal ini ditunjukkan oleh hasil nilai $\mathrm{t}$ hitung $>\mathrm{t}$ tabel yakni $2,022>1,661$ dan nilai signifikan sebesar $0.046<$ 0.05 . Dengan demikian penelitian ini menerima $\mathrm{H}_{3}$.

4. Secara parsial produksi berpengaruh positif dan signifikan terhadap pendapatan. Hal ini ditunjukkan oleh hasil nilai $\mathrm{t}$ hitung $>\mathrm{t}$ tabel yakni $53,131>1,661$ dan nilai signifikan sebesar $0.000<$ 0.05 . Dengan demikian penelitian ini menerima $\mathrm{H}_{4}$.

\section{Hasil Uji F}

Dengan ketentuan apabila nilai $F_{\text {hitung }}>$ dari $F_{\text {tabel }}$ maka $\mathrm{H}_{5}$ diterima, jika $\mathrm{F}_{\text {hitung }}<\mathrm{F}_{\text {tabel }}$ maka $\mathrm{H}_{1}$ ditolak. Artinya apabila $F_{\text {hitung }}>$ dari $F_{\text {tabel }}$ maka terdapat pengaruh pengalaman usaha, usia, waktu kerja dan produksi terhadap pendapatan. Secara simultan pengalaman usaha, usia, waktu kerja dan produksi berpengaruh terhadap pendapatan dimana $F_{\text {hitung }}>F_{\text {tabel }}$ yaitu $1762,362>2.520$ dan nilai signifikan sebesar $0.000<0.05$, sehingga menerima $\mathrm{H}_{5}$.

\section{Koefisien Determinasi $\left(\mathbf{R}^{2}\right)$ dan Korelasi $(R)$ Koefisien Determinasi $\left(\mathbf{R}^{2}\right)$}

Koefisien determinasi dilakukan untuk melihat seberapa besar kemampuan variabel indepen den secara bersama-sama memberi penjelasan terhadap variabel dependen dimana nilai $\mathrm{R}^{2}$ berkisar antara 0 sampai $1 \quad\left(0<\mathrm{R}^{2}<1\right)$ semakin besar nilai $\mathrm{R}^{2}$ maka semakin besar variasi variabel dependen atau untuk melihat seberapa besar pengaruh variabel independen terhadapvariabel dependen. Gujarati, (2003)

Berdasarkan Tabel 4.3 diatas hasil uji Koefisen determinasi $\mathrm{R}^{2}$ dengan regresi linier berganda, maka yang di lihat dari Ajudted $R$ Square yaitu sebesar 0,9861 atau 98,61\%. Hasil ini berarti pengalaman usia, waktu kerja dan produksi terhadap pendapatan sebesar $98,61 \%$. Sedangkan sisanya di pengaruhi oleh faktor-faktor lain di luar model.

\section{Koefisien Korelasi (R)}

Koefisien Korelasi (R) adalah untuk melihat pengaruh variabel independen terhadap variabel dependen berpengaruh kuat secara positif atau 
berpengaruh kuat secara negatif.R terletak antara (-1 $<\mathrm{R}<1$ ). Hasil yang diperoleh berdasarkan Tabel di atas untuk koefisien determinasi $\left(\mathrm{R}^{2}\right)$ adalah sebesar 0,9930 maka koefisien korelasi $(\mathrm{R})$ adalah sebesar $\sqrt{R^{2}}=$ yaitu 0,9930 . Hasil ini berhubungan kuat secara positif, karena nilai $\mathrm{R}$ mendekati positif $(+1)$.

\section{Pembahasan}

\section{a) Pengaruih Pengalaman Usaha Terhadap pendapatan}

Hasil dari penelitian ini menunjukkan bahwa pengalaman usaha berpengaruh positif dan signifikan terhadap pendapatan. Hasil dari penelitian menunjuk kan bahwa apabila meningkatnya pengalaman usaha maka pendapatan usaha juga akan semakin meningkat.

Hasil penelitian ini mendukung pendapat Sukirno (2004) Lamanya suatu usaha dapat menimbul kan pengalaman berusaha, di mana pengalaman dapat mempengaruhi pengamatan seseorng dalam bertingkah laku. Lama pembukaan usaha dapat mempengaruhi tingkat pendapatan, lama seorang pelaku bisnis menekuni bidang usahanya akan mempengaruhi produktivitasnya. Semakin lama menekuni bidang usaha perdagangan akan semakin meningkatkan pengetahuan tentaing selera atau pun perilaku konsumen.

Lamanya seorang pelaku bisnis menekuni bidang usahanya akan mempengaruhi kemampuan professionalnya. Semakin lama menekuni bidang usaha perdaagangan akan semakin meningkatkan pengetahuan tentang selera atau pun perilaku konsumen. Keterrampilan berdagang makin bertambah dan semakin banyak pula relasi bisnis maupun pelanggan yang berhasil dijaring (Asmie, 2008).

Hasil penelitian Firdausa dan Arianti (2014) menunjjukkan bahwa Variabel lama usaha berpengaruh terhadap jumlah pendapatan pedagang kios di pasar Bintoro Demak. Hasil penelitian Prisatya (2013) menunjukkan bahwa pengalaman usaha berpengaruh terhadap pendapatan pedagang. Prisatya (2013) mengemukakan pengalaman usaha adalah patokan tentang lama waktu atau masa kerja yang telah dijalani seseorang agar dapat memahami tugas - tugas suatu pekerjaan dengan baik. Pengalaman usaha menentukan keterampilan seseorang dalam melakukan salah satu tugas tertentu, dan pengalaman usaha dapatt berdampak posiitif atau negatiif terhadap kemampiuan seseorang.tersebut, sehingga dapat mengembangkan bisnis usaha dengan lebih baik lagi.

\section{b) Pengaruh Usia Terhadap Pendapatan}

Hasil dari penelitian ini menunjukkan bahwa usia berpengaruh negatif dan signifikan terhadap pendapatan. Hasil penelitian menunjukkan bahwa apa bila meningkatnya usia maka pendapatan akan semakin rendah. Pekerja lebih muda cenderung mengalami ketidak berdayaan yangg lebih tinggii bila diibandingkan dengaan pekerja yang lebiih tua, Almuntahar, dkk, (2016). Hal ini dapat terjadi dikarenakan pekerja yang lebih muda cenderung rendah pengalaman kerjanya jika di bandingkan dengan pekerja yang lebih tua, atau pun disebabkan karena faktor lain seperti pekerja yang lebih tua lebih stabil, lebih matang, mempunyai pandangan yang lebih seimbang terrhadap kehidupan sehingga tidak mudah mengalami tekanan mental atau ketidak berdayaan dalam pekerjaan.

\section{c) Pengaruh Waktu Kerja Terhadap pendapatan}

Hasil dari penelitian ini menunjukkan bahwa waktu kerja berpengaruh positif dan signifikan terhadap pendapatan. Dari hasil penelitian menunjukkan bahwa apabila meningkat nya waktu kerja maka pendapatan usaha juuga aakan semakin meningkat.

Jam kerja merupakaan lama waktu yang diigunakan untuuk menjalankan usaha ,yang dimulai sejak persiapan sampai usaha tutup. Hasil darii penelitian Jafar dan Tjiptoroso dalam Firdausa dan Ariyanti (2012) membbuktikan adanya hubunggan langsung antara jam kerja dengan tingkat pendapataan. Setiap penambahan waktu operasi akan makin membuka peluang bagi bertambahnya omzet penjualan.

Widyatama (2015) menyatakan pendapatan pada sektor informal itu sangat dipengaruhi oleh output yangg terjual. Maka jam kerja sangat berpengaruh dalam menentukan output yang terjual. Dengan teori alokasi waktu dimana pendapatan daapat ditingkatkan melalui penambahan jam kerja dengan mengurangi waktu luang atau waktu senggang yang tersedia. Menurut Widyatama (2015) Jam kerja mempengaruhi tingkat peendapatan yang diterima peedagang, dimana setiap penambahan jam kerja dapat meningkatkan pendapatan yang diterima pedagang sembako.

Analisis jam kerja merupakan bagian dari teori ekonomii mikro, khususnya pada teori penawaran tenaga kerja yaitu tentang kesediaan individu untuk bekerja deengan harapan memperoleh penghasilan atau tidak bekerja dengan konsekuensi mengorbankan pengahasilan yang sehiarusnya ia dapat kan. 
Kesediaan tennaga kerja untuk dengan jam kerja panjang atau pendek adalah merupakan keputtusan indiviidu (Wicaksono,2011).

Dari hasil penelitian ini sejalan deengan peneliitian sebelumnya yang dilakukan oleh Firdausa dan Arianty (2013), Ikramuddin dan Wahyuddin (2012), Puspita (2013) dan priyandika (2014) yang menyimpulkan baahwa jam kerja berpengaaruh terhadap peningkatan pendapatan pedagang.

\section{d) Pengaruh Produksi Terhadap pendapatan}

Hasil dari penelitian ini menunjukkan bahwa produksi berpengaruh positif dan signifiikan terhadap pendapatan. Hasil dari penelitian menunjukkan bahhwa apabila meningkatnya produksi maka pendapatan usaha jugga akan semakin meningkat.

Suratiyah (2006) menyatakan bahwa jika permintaan akan produksi tinggi maka harga di tingkat petani akan tinggi pula, sehingga dengan biaya yang sama petani akan memperoleh pendapatan yang lebih tinggi. Sebaliknya, jika petani telah berhasil meningkatkan produksi, tetapi harga turun maka pendapatan petani akan turun pula

Produksi adalahh penciptaan atau penambahan faedah, bentuk, waktu dan tempat atas faktor-faktor produksi sehiingga lebiih bermanfaat bagi pemenuhan kebutuhaan manusia. Assauri (2004) istilah produksi dan operasi sering digunakan dalam suatu kelompok yangg menghasilkan pengeluaran atau output, baik yang berupa barang maupun jasa. Secarra umum produksii diartikan sebagaii suatuu kegiatan atau proses yang mendistribusikan masukan (input) menjadi hasil keluaran (output).

Produksii merupakann salah sattu fungsi perusahaan dalam menghasilkan barang atau jasa melalui proses produksii. Paada hakekatnya produksi adalah kegiatan yang dapatt menimbulkan tambahan manfaat atau penciptaan faedah baru (Ahyari,2002). Produksi merupakann suatuu kegiatan yang memproses berbagai faktor produksi (input) menjadi barang lain (output) yangg mempunyai daya guna dan hasil guna yaang lebiih besarr dari semula (Prawirosentono, 2007).

\section{PENUTUP}

\section{Kesimpulan}

Berdasarkan hasil penelitian dan pembahasan, maka peneliti mengemukakan kesimpulan sebagai berikut :

1. Pengalaman kerja berpengaruh positif dan signifikan terhadap pendapatan Petani Kelapa
Sawit di Kecamatan Ranah Batahan Kabupaten Pasaman Barat.

2. Usia berpengaruh negatif dan signifikan terhadap pendapatan Petani Kelapa Sawit di Kecamatan Ranah Batahan Kabupaten Pasaman Barat.

3. Waktu kerja berpengaruh positif dan signifikan terhadap pendapatan Petani Kelapa Sawit di Kecamatan Ranah Batahan Kabupaten Pasaman Barat.

4. Produksi berpengaruh positif dan signifikan terhadap pendapatan Petani Kelapa Sawit di Kecamatan Ranah Batahan Kabupaten Pasaman Barat.

5. Pengalaman usaha, usia, waktu kerja dan produksi berpengaruh terhadap pendapatan Petani Kelapa Sawit di Kecamatan Ranah Batahan Kabupaten Pasaman Barat.

\section{Saran}

1. Bagi Masyarakat, dengan adanya penelitian ini diharapkan masyarakat dapat memaksimalkan hasil produksi kepala sawit dengan mempertimbangkan berbagai aspek seperti pengalaman kerja.

2. Bagi Pemerintah, diharapkan pemerintah dapat menstabilkan harga kelapa sawit sehingga petani dapat memperoleh pendapatan yang lebih tinggi.

3. Bagi Petani Kelapa Sawit, diharapkan dengan memperhatikan factor jam kerja dalam rangka untuk menunjang pendapatan yang akan di hasilkan Karena jam kerja akan mempengaruhi pendapatan.

4. Bagi peneliti selanjutnya untuk dapat menambah jumlah variabel dalam penelitian selanjutnya sehingga akan menghasilkan pengaruh yang lebih besar terhadap pendapatan seperti modal usaha.

\section{DAFTAR PUSTAKA}

Ahmad, Su'ud, 2007, Pengembangan ekonomi mikro, Nasional Conference, Jakarta.

Ahyari, Agus, 2002, Manajemen produksi perencanaan sistem produksi, edisi empat, Yogyakarta : BPFE 
Almutahar, F. F., Wardhani, N., \& Rafie. (2014). Pengaruh Usia, Pengalaman Kerja, Disiplin Kerja, dan Motivasi Kerja Terhadap Produktivitas Pekerja [The Influence of Age, Work Experience, Work Discipline and Work Motivation on Worker Productivity]. Jurnal Mahasiswa Teknik Sipil Universitas Tanjungpura.

Asmie, Poniwati (2008), Analisis Faktor-faktor yang Mempengaruhi Tingkat Pendapatan Pedagang Pasar Tradisional di Kota Yogyakarta, Jurnal Penelitian,Yogyakarta.

Assauri Sofyan. 2004. Manajeman Produksi Dan

Operasi. Jakarta : Fakultas Ekonomi

Universitas Indanesia

Firdausa, R. A., \& Arianti, F. (2012). Pengaruh Modal Awal, Lama Usaha dan Jam Kerja Terhadap Pendapatan Pedagang Kios di Pasar Bintoro Demak. Diponegoro Journal Of Economics, 2(1), 1-6. https://doi.org/10.21009/JPEB.006.1.1

Gehozali, Imam, 20012,Aplikasi: Analisis Multivariate Dengan Program SPSS.Badan Penerbit Universitas Diponegoro: Semarang. Komaruddin, 2006, Ensiklopedia Manajemen.

Penerbit Bumi Aksara,Jakarta

Lubis, A.U. 2008. kelapa Sawit (Elaeis guineens,is Jacq)di Indonesia Edisi ke2 Pusa,t Penelitian Kelapa Sawit. Medan

Mahyu Danil, 2013. Pengaruh Pendapatan terhadap Tingkat Konsumsi pada Pegawai Negeri Sipil di Kantor Bupati Kabupaten Biruen, Jurnal Ekonomika Universitas Almuslim Biruen Aceh.

Mardikanto, Totok. 2007. Penyuluhan Pembangunan Kehutanan. Pusat Penyuluhan Kehutunan Republik Indonesia. Jakarta.

Milfitra W, 2016,Analisis Pendapatan Usaha Tani Padi Sawah Didesa Ruang Kecamatan Rokan IV Kota Kabupaten Rotan Hulu. Universitas Pasir Panggaraian, Rokan Hulu.
Nano Ismanto, 2005, Pengaruh Pengalaman Kerja Dan Disiplin Kerja Terhadap Produktivitas Kerja Karyawan Perusahaan Speaker Aktif Arofah Elektronik Di Desa Gribig Kecamatan Gebog Kabupaten Kudus. Universitas Negeri Semarang.Skripsi.

Prawirosentono Suryadi. 2007. Manajemen Operasi Edisi Empat. Jakarta : Bumi Aksara.

Prisatya, Unda Rikmana Dean, (2013),Analisis FaktorFaktor Yang Mempengaruhi Tingkat Pendapatan Pemilik Usaha Industri KecilMenengah (Studi Kasus Industri KecilMenengah Makanan Ringan di Desa Talok Kecamatan Turen Kabupaten Malang).Fakultas Ekonomi dan Bisnis Universitas Brawijaya.

Priyandika, Akhbar Nurseta. (2014)“Analisis Pengaruh Jarak, Lama Usaha, Modal, Dan Jam Kerja Terhadap Pendapatan Pedagang Kaki Limakonveksi (Studi Kasus Di Kelurahan Purwodinatan Kota Semarang)". Universitas Diponegoro. Semarang.

Puspita, Jelita (2013), Pengaruh Kemampuan Pedagang Dan KondisiPasar Terhadap Pendapatan Bersih Pedagang Kaki Lima Di Pasar Induk Pagar Dewa Kota Bengkulu.Institut Agama Islam Negeri Bengkulu.

Satrio Adi Setiawan, 2010, Pengaruh Umur, Pendidikan, Pendapatan, Pengalaman Kerja Dan Jenis Kelamin Terhadap Lama Mencari Kerja Bagi Tenaga Kerja Terdidik Di Kota Magelang, Universitas Diponegoro, Jurnal.

Silalahi, Ulber (2012). Metode Penelitian Sosia. PT. Radika Aditama: Bandung.

Soediyono, (2009). Metode Penelitian Administrasi. Penerbit Alfabeta: Bandung.

Soediyono, 2009, Metode Penelitian Kuantitatif Kualitatif dan R\&D, Bandung: Alfabeta.

Sukirno, Sadono. (2004). Pengantar Teori Makroekonomi. Jakarta: PT Raja. Grafindo Persada

Suparto.2014. Analisa Korelasi Variabel-variabel yang Mempengaruhi Mahasiswa dalam Memilih Perguran Tinggi. Jurnal IPTEK. 
Supranto, J. (2001). Statistik Teori dan Aplikasi. Edisi Keenam.Erlangga, PT. Gelora Aksara Pratama: Jakarta

Suratiyah. 2006.Ilmu Usahatani.Penebar Swadaya. Jakarta.

Wicaksono, Ananto Sarono (2011). Analisis Pengaruh Rasio Keuangan terhadap Modal Saham, Jurnal Penelitian.

Widyatama, D. (2015). Analisis Faktor-Faktor Yang Mempengaruhi Pendapatan Pedagang Sembako Di Pasar Besar Kota Malang. Jurnal Ilmiah Mahasiswa FEB. http://jimfeb.ub.ac.id/index.php/jimfeb/articl e/download/1802/1652

Winarno, Wing Wahyu (2009).Analisis Ekonometrika dan Statistika Dengan Eviews,Edisi Kedua Sekolah Tinggi Ilmu Manajemen YKPN: Yokyakarta 
